\title{
LUTERS UN VIN̦A IETEKME PĒC 500 GADIEM - AKTUĀLAIS REDZĒJUMS NO VĀCIJAS
}

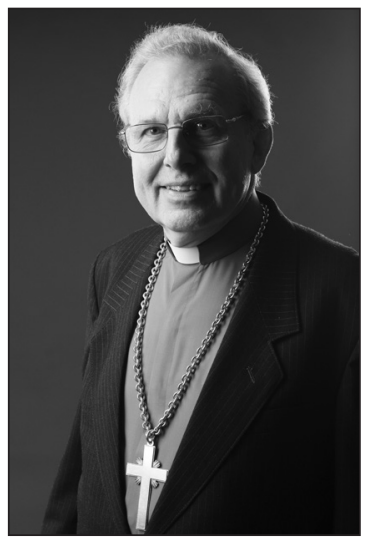

Elmārs Ernsts Rozītis ir Latvijas Evaņgèeliski luteriskās baznīcas ārpus Latvijas (LELBĀL) emeritētais arhibīskaps. Dzimis 1948. gada 30. martā Eslingenē. Studējis Tībingenes (1967-1969, 1971-1973), Hamburgas (1969-1970) un Vīnes (1970-1971) evaņgéēliskās fakultātēs, beidzot ar fakultātes eksāmenu (1973) un Virtembergas baznīcas otro eksāmenu (1975). LELB mācītājs (1973-1982) un prāvests (1982-1994) Vācijā, LELBĀL arhibīskaps (1994-2015). Regulāri publicējies akadēmiskos izdevumos, kā Universitas (Pietāte 1969), Acta Baltica (1978/1979), Kirche im Osten (no 1978) un Baznīcas izdevumos, kā Baznīcas Gadagrāmata (izd. LELBĀL), mēnešrakstos un laikrakstos. Lasījis lekcijas LU Teolog̣ijas fakultātē Jaunā un Vecā Derībā (1991, 1992, 1994).

Raksturvārdi: Mārtinšs Luters, reformatori, Vācija, Vitenberga, ekumeniskā atvērtība.

2017. gads - Mārtiņa Lutera 95 tēžu publikācijas Vitenbergā jubilejas gads - ir pagājis. Tā ir laba iespēja ievērot dažas specifiskas iezīmes, kādas piemīt M. Lutera ietekmei Vācijā un no Vācijas skata punkta. Centīšos uz tādām norādīt, nepretendējot uz pilnīgumu, jo šādai tematikai būtībā atbilstu disertācijas apjoms.

Ir labi apzināties lielo atvērtību un dažādību, kādā tika atzīmēta reformācijas jubileja. Protams, Vitenberga un tradicionālās "Lutera vietas", kā Eislēbene, Eizenaha ar Vartburgu, Erfurte, Vormsa, piedzīvoja īpašu uzmanību, kaut arī nenotika dažu sagaidītais cilvēku masu pieplūdums. Tas nemazināja cieņu iepretim M. Luteram, ka šajā gadā tika ievērotas ļoti daudzas personas, kuras blakus viņam vai tuvākā vai tālākā sadarbībā vai mijiedarbībā ar viņu savā vietējā vidē pārstāvēja reformācijas idejas un iestājās par to îstenošanu. Līdzās Ulriham Cvinglijam (Ulrich Zwingli, 1484-1531) un Žanam Kalvinam
(Jean Cauvin, 1509-1564) šeit minami humānisti Deziderijs Erasms (Desiderius Erasmus, 1466/9-1536), Filips Melanhtons (Philipp Melanchthon, 1497-1560) un daudzās personības, kuras palīdzēja ieviest reformāciju savā vidē: Vācijas un visas Eiropas ziemelos, piem., Johans Bugenhāgens (Johannes Bugenhagen, 1485-1558); Vācijas dienvidos, piem., Ambrozijs Blārers (Ambrosius Blarer, 1492-1564); arī lielais reformatoru skaits Eiropas austrumos, kā Polijā, Ungārijā, vai Eiropas rietumos vai dienvidos, arī zemēs, kurās pretreformācija vēlāk daḷēji sekmīgi centās izdzēst vinuu pēdas. 1517. gada zīmē gandrīz katra vieta Vācijā tiecās apzināties tieši savu īpašo reformācijas vēsturi.

Šajā kopsakarā ir raksturīgi, ka par pirmo reformācijas gada lielsarīkojumu varam uzskatīt ekumenisko dievkalpojumu Lundas katedrālē 2016. gada 31. oktobrī Zviedrijas arhib̄̄skapes Antjes Jakelēnas (Jackelén) un Romas katoḷu pāvesta Franciska vadībā, ${ }^{1}$ -

Baznīcas Gadagrāmata (turpmāk - BGg) 2018, 243. 
un personīgi priecājos, ka varēju tajā piedalīties, sēžot blakus Vidusvācijas Evaṇgēliskās baznīcas (kuras teritorijā atrodas "Lutera vietas") bīskapei Ilzei Junkermanei (Junkermann). Raksturīgi tas bija tan̄̄ ziṇā, ka tieši Vācija atbalstīja to, ka šis jubilejas sarīkojums notiek ārpus Vācijas, noraidot priekšstatu, it kā reformācija būtu bijusi "vācu lieta". Tādēl arī sava veida kulminācija bija reformācijas jubilejas svētki Pasaules Luterāņu asamblejas ietvaros Namībijā 2017. gada maijā, kurā piedalījās Latvijas Evaṇgēliski luteriskās baznīcas ārpus Latvijas (turpmāk - LELBĀL) arhibīskape Lauma Zušēvica ${ }^{2}$, bet Latvijas Evaņgēliski luteriskā baznīca (LELB) izšķ̄īāās nepiedalīties. Un raksturīgi tanī ziņā, ka reformāciju svinēja ekumeniskā veidā - ne kā vienas konfesijas svētkus, bet kopā priecājoties par atjaunošanos, ko ar reformāciju Dievs dāvājis visai savai Baznīcai. Šì tuvā evaṇgèliskās un Romas Katoḷu baznīcas sadarbība Vācijā novedusi līdz tam, ka atsevišksu zemju (pavalstu) valdību priekšlikums - Ziemelıācijas pavalstīs noteikt par reformācijas dienu 31. oktobri kā publisku svētku dienu - no paša sākuma guvis plašu atbalstu no abām konfesijām. Agrākās Austrumvācijas teritorijā tā jau tāda skaitās kopš Vācijas apvienošanās, un 2017. gadā to publiski svinēja visā Vācijā. Minētā tuvā sadarbība novedusi arī līdz tam, ka Vācijas Romas katoḷu bīskapu konference ar lielu vairākumu nolēmusi piel̦aut iespēju, ka pie dievgalda var piedalīties abi laulību partneri, kur viens ir piederīgs evangéēliskai, bet otrs Romas katoḷu konfesijai. ${ }^{3}$ Daži vinuu bīskapi par to gan nosūtījuši sūdzības vēstuli uz Romu. ${ }^{4}$ Toties latviešu luterāṇu draudzes Vācijā jau kopš Otrā pasaules kara beigām bijušas atvērtas pie sava dievgalda pieņemt arī citu konfesiju piederīgos, jo svarīgāk ir sekot kopīgi mūsu aicinātājam Jēzum Kristum, nekā veidot it kā ekskluzīvus svētību mantot gribētāju klubiņus. Katrā ziņā it īpaši Vācijā reformācijas atcere notika izteikti ekumeniskā veidā, vai tas būtu zemju baznīcu ietvaros kā Virtemberga $\bar{a}^{5}$ vai neskaitāmos sarīkojumos, dievkalpojumos, pilsētu vai draudžu svētkos, izstādēs, referātos un teātra izrāžu vai mūziklu uzvedumos cauru gadu.

Piedaloties Pasaules Luterāṇu federācijas Vācijas nacionālajā komitejā, varu apliecināt, ka jubilejas gada organizācija jau sākās pirms krietni vairāk nekā 10 gadiem. Viens no pirmsākumiem bija ideja par Lutera dārza iekārtošanu Vitenbergā. Ideja izrietēja no M. Luteram raksturīgā teikuma (ja arī tas laikam nav viņa paša tà sacīts) - pat ja viņš zinātu, ka rīt būs pastardiena, viņš šodien vēl dēstītu ābelīti. Luterāṇu baznīcas un kopienas plašā pasaulē, bet arī citas konfesijas bija laipni aicinātas piedalīties šajā akcijā, stādot vienu koku Lutera dārzā Vitenbergā, bet otru - māsas koku - pašas savā zemē. Atsaucība bija ārkārtīgi plaša, un tika sasniegts mērkis - līdz jubilejas gadam iestādīt ne mazāk kā 500 koku ar atbilstošo skaitu māsu koku. Vadoties pēc kopplāna un plāksnītes pie koka, jūs varat tur atrast arī kā LELB, tā LELBĀL koku. N̦emot vērā LELBĀL plašo darbības lauku, mums pat nav viens māsas koks vien, bet tādi aug Rovfantā Lielbritānijā, Amerikā pie mūsu baznīcām Vašingtonā un Sietlā, kā arī Austrālijā. ${ }^{6}$ 2017. gada 25. novembrī līdz ar pārējiem vācu nacionālās komitejas locekḷiem biju liecinieks, kā Jeruzalemē Eḷlas kalnā stādīja vienu no pēdējiem māsu kokiem vietējās palestīniešu baznīcas bīskaps Munibs Junāns, Vācijas luterāṇu baznīcu vadošais bīskaps Gerhards Ulrihs (Ulrich) kopā ar dārza arhitektu Andreasu Kiparu (Milāna/Duisburga) kā šīs idejas plānotāju. Arī šeit bija jūtamas vadlīnijas to darīt plašā, ne šauri nacionālistiskā garā un lielā ekumeniskā atvērtībā.

To pašu var teikt par reformācijas 500 gadu jubilejai veltīto starptautisko izstādi, kura Vitenbergā notika vienlaikus daudzās sarīkojumu vietās 2017. gada vasarā. ${ }^{7}$ Laiks bija sadalīts posmos, un LELBĀL uzṇēmās atbildību (no 2. līdz 6. augustam)

2 BGg 2018, 210-211.

3 Evangelischer Pressedienst (epd) (23.02.2018.); Evangelisches Gemeindeblatt für Württemberg (turpmāk saīsināts - EGfW), 7/2017 (12.02.2017.), 3 .

4 epd (04.04.2018.).

\footnotetext{
EGfW 12/2017 (19.03.2017.), 1, 4-7; EGfW 40/2017 (01.10.2017.), 10-11.

6 BGg 2012, 246-247.

7 EGfW 31/2017 (30.07.2017.), 6; EGfW 38/2017 (17.09.2017.), 2.
} 
iepazīstināt ar reformācijas gaitu un tradīcijām no pirmsākumiem Rīgā līdz šai dienai. Galvenie organizētāji bija bazn. padomnieks Pēteris Vīgants un Inta Vīgante līdz ar prāv. emer. Dr. Frici Kristbergu un mani. Ievērību guva prof. Dr. Vilfrīda Hērles (Wilfried Härle) un vina kundzes māc. Dr. Ilzes Kezberes-Hērles muzikāli biogrāfiskais sniegums par Luteru un viņa kundzi Katarīnu fon Boru. Sadraudzējāmies ar GEKE (Eiropas Evaņgēlisko baznīcu apvienība, kurā ir arī reformāti, metodisti u. c.) pārstāvjiem no Ungārijas, ēkā netālu no mūsu lielās sarīkojumu telts.

Tā kā Latvijas tematikai veltīts īpašs raksts, šeit tikai norādīšu uz personāla un finansiālo atbalstu no Vācijas Ārlietu ministrijas, Vācu evaṇg̣ēliski luteriskās baznīcas Vācijā un Latvijā $\bar{\beta}^{8}$, kā arī citām vācu iestādēm, piedaloties reformācijas atceres augsta līmeņa sarīkojumos Latvijas Universitātē vai arī Nacionālajā bibliotēkā. Reformācijas kopsakarā šajā gadā Vācijā tika daudzkārt veltīta uzmanība arī īpaši Latvijai. ${ }^{9}$

Liels nopelns plašas ievērības sasniegšanā sabiedrībā, medijos un līdz pat atsevišşo draudžu līmenim bija agrākai Hanoveres baznīcas un uz īsāku laiku pat visas Vācijas Evaṇgēeliski luteriskās baznīcas vadošai bīskapei Margotai Kesmanei (Käßmann). Viṇa uz vairākiem gadiem līdz pat šim pavasarim bija iecelta par oficiālo "reformācijas vēstnieci". ${ }^{10}$ Dotība būt personīgi pārliecinošai viṇā apvienojās ar spējām arī sarežğìtas lietas izteikt vienkārši un saprotami. Tādēl intervijās un sarīkojumos viṇa bija ideāla reformācijas seja. Ecclesia est semper reformanda (lat. - Baznīca arvien ir atjaunojama) nedrīkst būt sauklis, ko dažs labs viltīgi attiecina tikai uz mainīgām laika parādībām, lai savām dogmām joprojām nemain̄̄gi censtos pakḷaut pašu Dievu, it kā Viņš nevarētu, negribētu un nedrīkstētu radīt neko būtiski jaunu, it īpaši ne Baznīcā.

${ }^{8}$ Līdz Otrajam pasaules karam vācu draudzes Latvijā veidoja savu īpašu diecēzi LELB ietvaros. Pēc Latvijas neatkarības atgūšanas 20. gs. 90. gados Vācu evangếeliski luteriskā baznīca Latvijā ir patstāvīga reliǵiska organizācija.

9 Skat., piem., Daces Balodes rakstu EGfW 31/2017 (30.07.2017.), 17 .

${ }^{10}$ EGfW 44/2017 (29.10.2017.), 7; KalRef 2015, 109.
Reformācijas atceres gadā Vācijā izcēla arī ievērojamo skaitu sieviešu personību, kurām bijusi svarīga loma M. Lutera mācības izplatīšanā. ${ }^{11}$ Reizē pievērsa uzmanību tam, ka sievietes kalpošana ordinētā amatā ir pamatota Bībelē un M. Lutera teologijāa . Jānorāda uz 2017. gadā izdoto prof. Dr. Vilfrīda Hērles pāvestam Franciskam veltīto (!) grāmatu Kristus uzdevumā. Bībeles argumenti par labu sieviešu ordinācijai ${ }^{12}$, kurā sistemātiski atspēkoti visi arvien lietotie pretargumenti. Kopš, pateicoties mikrofonam, vairs nav nepieciešama balss, ar ko vajadzētu baznīcu piebḷaut, un kopš - arī pateicoties M. Lutera reformācijai - sievietes nav izslēgtas no izglīīibas, bet tā vin̄ām ir vismaz vienlīdzīga, vairs nepastāv neviens biblisks vai racionāls arguments pret sieviešu ordināciju. Vismaz luterāni Vācijā un tikpat kā visā Eiropā, piem., arī Igaunijāa, to tā redz, izṇemot dažus skaitliski un teoloǵiski nenozīmīgus šķeltnieciskus grupējumus.

Patīkami bija vērot, ka nemēgināja noklusēt to, kas M. Luteram bijis dziļi problemātisks. Jaunības gados viņa nostāja pret ebrejiem vēl bijusi samērā izprotoša, bet vēlāk naidpilna un izmantota kā pamats šausmīgām pēdējo gadsimtu necilvēcībām. ${ }^{13}$ L Loti dažādas domas var būt arī par M. Lutera viedokli attiecībā uz zemnieku nemieriem. ${ }^{14}$ N̦emot vērā viṇu demokrātiskās prasības, daudzi jautā, vai M. Luters, nosodot zemniekus un atbalstot valdošo iekārtu, nebija pārāk vienpusīgs, nokavējot vēsturisku kristīgās ticības sabiedrisku izpausmi. Pasaules Luterāṇu federācijas līmen̄̄ jau pirms vairākiem gadiem tikusi izteikta nožēla par luterāṇu pārestībām iepretim

${ }^{11}$ EGfW, 44/2017 (29.10.2017.), 6; KalRef 2015, 32.

12 Šì grāmata 2017. gadā vispirms iznāca vācu valodā ar nosaukumu Von Christus beauftragt. Ein biblisches Plädoyer für Ordination und Priesterweihe von Frauen, reizē izdota Evangelische Verlagsanstalt un katoḷu izdevniecībā Bonifatius, un Ilze Kiezbere-Hērle to tūlīt tulkoja latviešu valodā.

13 EGfW 24/2017 (11.06.2017.), 13; EGfW 45/2017 (05.11.2017.), 4-7; KalRef 2015, 89-91.

${ }^{14}$ EGfW 41/2017 (08.10.2017.), 16-17; KalRef 2015, 85-86. 
anabaptistiem. ${ }^{15}$ Plaši ticis norādīts uz dokumentu No konflikta uz kopību, kurā attiecībās ar Romas Katoḷu baznīcu cenšas atraisīties no liekiem apvainojumiem un saredzēt kopējo. ${ }^{16}$

Reformācijas jubilejas gadam sākoties, daudzi luterāņi paši baidījās no apnikuma, ja veselu gadu runās, rakstīs un raidīs par M. Luteru un reformāciju. Gada beigās kopējais atzinums tomēr ir, ka šāds apnikums neiestājās, drīzāk visā sabiedrībā bija izbrīns, cik daudzpusīga un vēl arvien aktuāla ir reformācija. Caurskatīju Virtembergas baznīcas (kurai pāri par 2 miljonu locekḷu - un šis skaits patiesi ir tās juridiskie locekḷi, nevis pielīdzināmi Latvijā minētiem it kā 700000 luterāṇu, no kuriem pat ne 50000 LELB nevar minēt kā savus pilntiesīgus locekḷus) nedēḷas izdevuma Evangelisches Gemeindeblatt für Württemberg 2017. gada 52 numurus: 36 numuros atrodas pārsvarā apjomīgi raksti par reformācijas aspektiem. Varam pieņemt, ka līdzīgi tas ir arī pārējās Vācijas baznīcās. Gandrīz katra no šīm baznīcām kā informatîvu palīdzību, lai nodarbotos ar reformāciju, izdeva arī tai veltītas

${ }^{15}$ KalRef 2015, 111.

${ }^{16}$ No konflikta uz kopību. Luterānnu un katoḷu kopīga reformācijas gadadienas atcere 2017. gada - šis Luterāṇu un Romas katoḷu vienotības komisijas ziņojums 2017. gadā izdots arī latviešu valodā kā Evangelische Verlagsanstalt un katoḷu izdevniecības Bonifatius 2013. gadā izdotā ziņojuma Vom Konflikt zur Gemeinschaft tulkojums. Ievērojams solis uz to ir bijusi Vienotā deklarācija par taisnošanas mācību (Joint Declaration on the Doctrine of Justification), ko 1999. gada 31. oktobrī parakstīja Romas Katoḷu baznīcas un Pasaules Luterāṇu federācijas pārstāvji. Protams, gadu gaitā nav trūcis arī kritiskas atsauksmes no abām - Romas katoḷu, kā arī luterāṇu - pusēm, bet to raksturojums pārsniegtu šì raksta iespējas. grāmatas vai burtnīcas. Arī šeit minēšu tikai vienu: Hanoveres Luterāṇu baznīcas (2,8 milj. locekḷ) izdevumu Kaleidoskop Reformation. Informativ - Individuell - Inspirierend (Kaleidoskops Reformācija. Informatīvi - Individuāli - Iedvesmojoši), 138 lapaspušu biezu, pateicoties lielam pieprasījumam vairākkārt pārspiestu. Tas pats atkārtojās arī atsevišķ o draudžu līmen̄̄, vinu iespiestos vai arī elektroniskos izdevumos. Un visas Vācijas apjomā minamas vairākas vēsturiskas filmas televīzijā, ar dažādu pieeju veltītas reformācijai kopumā vai arī saistošajai M. Lutera personībai. ${ }^{17}$

Protams, Vācijā, tāpat kā lielā vairumā Eiropas valstu, ir diezgan sekulāra sabiedrība un valstiska iekārta, kurā rūp̄igi ievēro, ka valsts un Baznīca ir škirtas, reizē atzīstot un regulējot abu mijiedarbību. M. Lutera priekšstats par to, ka Dievs šajā pasaulē darbojas laicīgās un garīgās norisēs kā ar labo un kreiso roku un ka ir labi abus aspektus lìdz ar to organizatoriskām izpausmēm nesajaukt, bet gan saskaņot, man škiet jūtams arī pašlaik. Federālā kanclere Angela Merkele (Angela Merkel) ir mācītāja meita, iepriekšejjais Valsts prezidents Joahims Gauks (Joachim Gauck) bija mācītājs, un lielam vairumam politiķu ir bijusi vai ir aktuāla saistîba ar baznīcām - pat politikiiem no partijām, par ko varētu brīnīties. Tomēr vini to nenoliedz un nekaunas publiski apliecināt, bet arī īpaši neizceḷ un nemēgina izmantot neatbilstošā veidā. ${ }^{18} \mathrm{Ja}$ to tā redz, M. Luters 500 gadus pēc savām tēzēm šeit var būt gandarīts.

${ }_{17}$ EGfW 7/2017 (12.02.2017.), 12-13, 27.

18 Pašreizējais Vācijas Valsts prezidents Franks Valters Šteinmeiers (Frank-Walter Steinmeier) ir Berlīnes evaņgéliskās reformātu Betlēmes draudzes loceklis. Par viṇu un visiem viṇa priekštečiem skat. EGfW 8/2017 (19.02.2017.), 9.

\section{VĒRES}

Kaleidoskop Reformation: Informativ - Individuell - Inspirierend (turpmāk saīsināts - KalRef) (2015) Hannover : Evangelisch-Lutherische Landeskirche Hannovers. 